\title{
Anthropogenic debris flows in Sakhalin
}

\author{
Leonid E. Muzychenko*1 \\ Ekaterina N. Kazakova ${ }^{2}$
}

\begin{abstract}
${ }^{1}$ Sakhalin Department of Far East Geological Institute, FEB RAS, Yuzhno-Sakhalinsk, Russia

${ }^{2}$ Special Research Bureau for Automation of Marine Researches, FEB RAS, Yuzhno-Sakhalinsk, Russia.
\end{abstract}

*E-mail: allixev@yandex.ru

\begin{abstract}
RUS }}$
The problem of the interaction between human activity and mudflow processes is currently important for the Sakhalin Island, where debris flow occurrences have been repeatedly observed in recent decades. At the present time, this interaction increases due to the extension urban territories into debris flows transit and accumulation zones, including rock spoil heaps in debris flow prone areas. This paper describes several debris flow occurrences associated with human activity in Sakhalin, as well as the characteristics of anthropogenic debris flows and consequent damage. An evaluation of changes in debris flow activity in flow prone zones was carried out based on field observations and satellite image analysis. It is suggested that the most serious damage is caused by debris flows occurences from quarries because of the large sizes of rock spoil heaps.
\end{abstract}

\section{Keywords}

debris flow, anthropogenic impact, mudflow, anthropogenic debris flow

For citation: Muzychenko L.E., Kazakova E.N. Anthropogenic debris flows in Sakhalin. Geosistemy perehodnykh zon = Geosystems of Transition Zones, 2020, vol. 4, no. 3, pp. 359-368. (In Russ.). https://doi.org/10.30730/gtrz.2020.4.3.359-368

Для цитирования: Музыченко Л.Е., Казакова Е.Н. Антропогенные сели на Сахалине. Геосистемы переходных зон, 2020, т. 4, № 3, с. 359-368. https://doi.org/10.30730/gtrz.2020.4.3.359-368

\section{References}

1. Atlas Sakhalinskoy oblasti [Atlas of Sakhalin Region]. 1967. M.: Glavnoye upravleniye geodezii i kartografii pri Sovete ministrov SSSR [Chief Directorate of Geodesy and Cartography under the Council of Ministers of the USSR], $135 \mathrm{p}$.

2. Efremov Yu.B. 2012. [Antropogenic debris flows in the basin of the Mzymta river]. In: Trudy mezhdunar. seminara $k$ 10-letiyu katastrofy na lednike Kolka 20 sentyabrya $2002 \mathrm{~g}$. «Opasnyye prirodnyye protsessy v gorakh: uroki Karmadonskoy katastrofy» [Proceedings of International Workshop for the 10th anniversary of the catastrophe at the Kolka glacier September 20, 2002. "Natural hazards in mountains: lessons to be learned"]. Vladikavkaz: Iriston, 1516.

3. Gensiorovskiy Yu.V. 2011. Ekzogennyye geologicheskiye protsessy i ikh vliyaniye na territorial'noye planirovaniye gorodov (na primere o. Sakhalin) [Exogenous geological processes and their influence on the territorial planning of cities (on the example of Sakhalin Island)]: [extended abstract of cand. of geol. and miner. sciences diss.]. Irkutsk, 16 p.

4. Gensiorovskiy Yu.V., Kazakov N.A. 2009a. Aktivizatsiya ekzogennykh geologicheskikh protsessov na Yuzhnom Sakhaline 22-24 iyunya 2009 goda [Activization of exogenous geological processes in South Sakhalin on June 22-24, 2009]. Georisk [Geohazard], 2: 56-60. URL: http://www.geomark.ru/journals_list/zhurnal-georisk-22009/ (accessed 02.07.2020).

5. Gensiorovskiy Yu.V., Kazakov N.A. 2009b. [The impact of exogenous geodynamic and river channel processes on the pipeline route of the Sakhalin-2 project in the summer of 2009]. Georisk [Geohazard], 4: 41-45. URL: http://www.geomark.ru/journals_list/zhurnal-georisk-42009/ (accessed 02.07.2020). 
6. Gensiorovskiy Yu.V., Kazakov N.A., Rybal'chenko S.V. 2008. [Gidrometeorological conditions of periods of mass debris flow occurrence on Sakhalin Island]. In: Selevyye potoki: katastrofy, risk, prognoz, zashchita: Trudy Mezhdunar. konf., Pyatigorsk, 22-29 sent. 2008 g. [Debris flow: disasters, hazard, prediction, defence: Proceedings of the Intern. Conf., Pyatigorsk, September 22-29, 2008]. Pyatigorsk: Sevkavgiprovodkhoz, Mezhregion. obshchestv. org. «Selevaya assotsiatsiya» [Sevkavgiprovodkhoz, "Debris flow association" the Interregional public organization], 95-98. URL:http://www.fegi.ru/elibrary/articles/glaciology/496-gensiorovsky003/file (accessed 02.07.2020).

7. Gensiorovskiy Yu.V., Ukhova N.N., Shtel'makh S.I., Grin' N.N., Stepnova Yu.A. 2019. [Intensification of dynamic processes in areas with large linear objects associated with changes in the characteristics of soils]. Geodinamika $i$ tektonofizika = Geodynamics and Tectonophysics, 10(3): 697-714. https://doi.org/10.5800/GT-2019-10-3-0436

8. Kazakov N.A. 2014. Technogenic debris flow on the territory of Krasnaya Polyana. In: III International Conf. «Debris flows: Disasters, Risk, Forecast, Protection»: proceedings, Yuzhno-Sakhalinsk, September 22-26, 2014. YuzhnoSakhalinsk: Sakhalin Dep. of Far East Geological Institute of FEB RAS, 202-205. URL: http://www.fegi.ru/elibrary/conf/156-selevye-potoki-2014/file (In Russ.).

9. Kazakov N.A., Gensiorovskiy Yu.V. 2008. Ekzogennyye geodinamicheskiye i ruslovyye protsessy v nizkogor'ye o. Sakhalina kak faktory riska dlya neftegazoprovodov «Sakhalin-2» [Exogenous geodynamic and river channel processes in the low-mountains area of Sakhalin Island as risk factors for the "Sakhalin-2" oil and gas pipelines]. Geoekologiya. Inzhenernaya geologiya. Gidrogeologiya. Geokriologiya [Geoecology, Engineering geology, Hydrogeology, Geocryology], 6: 483-496.

10. Kazakova E.N., Kazakov N.A., Gensiorovskiy Yu.V. 2018. Debris flow protection on Sakhalin Island. In: Debris flows: Disasters, Risk, Forecast, Protection: Proceedings of the $5^{\text {th }}$ International Conf. Tbilisi, Georgia, 1-5 October 2018. Tbilisi: Universal, p. 351-356.

11. Muzychenko A.A., Pavlov V.S., Pavlov A.S. 2015. [Formation of antropogenic debris flows from the quarries (by the example of the "Listvennichnyy" quarry)]. In: Geodinamicheskiye protsessy i prirodnyye katastrofy. Opyt Neftegorska: Vseros. nauch. konf. s mezhdunar. uchastiyem: sb. materialov [Geodynamic processes and natural disasters. Experience of Neftegorsk: All-Russian Scientific Conf. with international participation: collection of proceedings]: in 2 vol. Ed. B.W. Levin, O.N. Likhacheva, vol. 2: 346-349. https://www.elibrary.ru/item.asp?id=29146655

12. Perov V.F. 1996. [Mudflow phenomena: Terminological dictionary]. M.: Izd-vo Moskovskogo un-ta [Publ. House of Moscow State University], 34 p. https://www.debrisflow.ru/wp-content/uploads/2015/09/Dictionary_Perov.pdf

13. Perov V.F. 2012. Selevedeniye [Mudflow studies]. M.: MGU [MSU], 271 p.

14. Polunin G.V. 1989. Dinamika i prognoz ekzogennykh protsessov [Dynamics and forecast of exogenous processes]. M.: Nauka, $232 \mathrm{p}$.

15. RD 52.30.238-90 1990. Rukovodstvo selestokovym stantsiyam i gidrograficheskim partiyam [Guidelines for mudflow runoff stations and hydrographic parties]. Iss. 1. M.: Gidrometeoizdat, 199 p.

16. Seleopasnyye rayony Sovetskogo Soyuza [Mudflow vulnerable areas of the Soviet Union]. 1976. Eds. S.M. Fleyshman, V.F. Perov. M.: Izd-vo MGU [MSU], 293 p.

17. Sokratov S.A., Seliverstov Y.G., Shnyparkov A.L., Koltermann K.P. 2013. Anthropogenic effect on avalanche and debris flow activity. Ice and Snow, 53(2): 121-128. (In Russ.). https://doi.org/10.15356/2076-6734-2013-2-121-128

18. Su W.X., Miller H.D.S. 1995. Waste pile stability and debris flow formation. The $35^{\text {th }}$ U.S. Symposium on Rock Mechanics (USRMS), 5-7 June, Reno, Nevada. Balkema, Rotterdam, 831-835.

19. Vinogradov Yu.B. 1980. Etyudy o selevykh potokakh [Mudflow studies]. Leningrad: Gidrometeoizdat, $144 \mathrm{p}$.

20. Yanites B.J., Webb R.H., Griffiths P.G., Magirl C.S. 2006. Debris flow deposition and reworking by the Colorado River in Grand Canyon, Arizona. Water Resources Research, 42(W11411). https://doi.org/10.1029/2005WR004847 